\title{
Potential blood-based markers of celiac disease
}

\author{
Hanna Bragde ${ }^{1 *}$, Ulf Jansson², Mats Fredrikson ${ }^{3}$, Ewa Grodzinsky ${ }^{4}$ and Jan Söderman ${ }^{1}$
}

\begin{abstract}
Background: Blood-based diagnostics has the potential to simplify the process of diagnosing celiac disease (CD). Although high levels of autoantibodies against tissue transglutaminase (anti-TG2) are strongly indicative of active $C D$, several other scenarios involve a need for additional blood-based CD markers.

Methods: We investigated the levels of messenger RNA (mRNA) in whole blood $(n=49)$ and protein in plasma $(n=22)$ from cases with active $C D(n=20)$, with confirmed $C D$ and normalized histology $(n=15)$, and without a $C D$ diagnosis $(n=14)$. Group differences were analyzed using Kruskal-Wallis one-way analysis of variance by ranks. We also investigated correlations between levels of potential markers, histopathology according to the modified Marsh scale, and CD risk gradient based on HLA type, using Spearman rank correlation. The relation between HLA-DQ2 gene dose effect and the expression levels of selected blood-based markers was investigated using the Mann-Whitney $U$ test. Finally, the diagnostic performance of anti-TG2, potential blood-based CD markers, and logistic regression models of combined markers was evaluated using receiver operating characteristic (ROC) curve analysis.
\end{abstract}

Results: CXCL11 protein levels and TNFRSF9 and TNFSF13B mRNA levels were identified as potential CD markers. These are all affected by or involved in the regulation of the NF-KB complex. CXCL11 protein levels and IL21 and IL15 mRNA levels were correlated with histopathology according to the modified Marsh scale, as were the established CD markers. HLA genotype risk and HLA-DQ2 gene dose effect did not show any significant relations with either the potential CD markers or the established CD markers. ROC curve analysis revealed a slight, non-significant increase in the area under the curve for the combined use of anti-TG2 and different constellations of potential blood-based CD markers compared to anti-TG2 alone.

Conclusions: The CD markers identified in this study further emphasize the significance of components related to NF-KB regulation in relation to CD. However, the relevance of CXCL11, TNFSF13B, TNFRSF9, and other NF-KB interacting proteins recognized by pathway analysis, needs to be further investigated in relation to diagnosis and monitoring of $C D$.

Keywords: Celiac disease, Molecular diagnostics, Blood-based biological markers

\section{Background}

Celiac disease $(\mathrm{CD})$ is defined as a "chronic small intestinal immune-mediated enteropathy precipitated by exposure to dietary gluten in genetically predisposed individuals" [1]. Autoantibodies against tissue transglutaminase (TG2) can be found in the blood, as can antibodies against endomysium, deamidated gliadin (DGP), and native gliadin (GL); and infiltration of intraepithelial lymphocytes (IELs) in the epithelium, elongation of the crypts, and destruction of villi is seen in the small intestine [2]. A strong genetic component is

\footnotetext{
* Correspondence: hanna.gustafsson.bragde@lj.se

'Division of Medical Diagnostics, Ryhov County Hospital, Jönköping, Sweden Full list of author information is available at the end of the article
}

evident in $\mathrm{CD}$, with the strongest association found in the $H L A$ region [3,4], primarily with DQ2 (DQA1*05/ $D Q B 1 * 02)$ and in a minority of CD patients with DQ8 $(D Q A 1 * 0301 / D Q B 1 * 0302)$ [5,6]. There is a gene dose effect of HLA-DQ2 [7], and risk gradients based on HLA type have been calculated $[8,9]$. A number of other risk loci containing multiple candidate genes have been associated with $\mathrm{CD}[3,4,10-12]$.

Current CD diagnostics primarily include antibody detection, mainly of Immunoglobulin A (IgA) autoantibodies against TG2 (anti-TG2), and confirmation of the diagnosis by histopathologic assessment of small intestinal biopsies [13]. The European Society of Paediatric Gastroenterology, Hepatology and Nutrition (ESPGHAN) Working 
Group on Coeliac Disease Diagnosis suggested in 2012 that children and adolescents with clear symptoms and anti-TG2 levels over 10 times the upper limit of normal (ULN), with a remission of symptoms on a gluten-free diet (GFD), could be diagnosed with CD without histopathologic assessment of an intestinal biopsy [14]. Additionally, the presence of HLA-DQ2 or DQ8 should be verified.

We have previously developed a discriminant analysis model based on gene expression data in duodenal biopsies. This model can discriminate between biopsies with and without histopathologic alterations indicative of $\mathrm{CD}$, and also indicate the level of histologic damage as well as mucosal recovery on a GFD [15]. The identification of blood-based markers which could reinforce the diagnostic value of anti-TG2, and perhaps indicate the level of histologic damage and mucosal recovery on GFD, would further simplify CD diagnostics.

In the present study, we investigated levels of candidate CD markers (messenger RNA [mRNA] and protein) in blood from celiac and non-celiac cases, and considered the possible added value of these candidate markers. We also explored the relations between candidate markers and enteropathy graded according to the modified Marsh scale [16], CD risk gradient based on HLA type [8], and HLA-DQ2 gene dose effect [7].

\section{Methods}

\section{Study subjects and samples}

Following written informed consent from parents/legal guardians, blood and duodenal biopsy specimens were collected from pediatric patients (Table 1) investigated for suspected CD or at follow-up on a gluten-free or gluten-containing diet, both for diagnostic purposes and for research purposes.
For diagnostic purposes, blood was collected in a blood tube containing polymer gel and clot activator (Becton, Dickinson and Company, Franklin Lakes, NJ) and centrifuged at $2400 \times \mathrm{g}$ for $5 \mathrm{~min}$ for serum isolation. The sera were stored at room temperature for a maximum of 10 hours after centrifugation, and then at $4{ }^{\circ} \mathrm{C}$ until the presence of CD-specific antibodies (anti-TG2 and antibodies against DGP [anti-DGP]) and antibodies against GL (anti-GL) was investigated, which occurred within 5 days of centrifugation. In six cases, the antibody tests were performed on plasma collected for research purposes. Multiple biopsy specimens were collected using an endoscope in all but one case, where a pediatric Watson capsule was used to extract a single biopsy specimen. The tissue was formalin-fixated and paraffin-embedded, and histopathologically assessed.

For research purposes, blood was collected both in EDTA blood tubes (Becton, Dickinson and Company) for DNA and plasma isolation, and in Tempus Blood RNA tubes (Life Technologies, Carlsbad, CA) for RNA isolation. An aliquot of EDTA blood for DNA isolation was removed, and the remaining blood centrifuged at $1500 \times \mathrm{g}$ for $10 \mathrm{~min}$ for plasma isolation. For two cases, one in the group with no indications of $\mathrm{CD}$ and one in the group with active CD (Table 1), blood for RNA purification was collected in EDTA blood tubes instead of Tempus tubes. Additionally, a biopsy specimen immersed in pre-chilled RNAlater RNA Stabilization Reagent (Qiagen, Hilden, Germany) was collected from all cases in the study. Biopsies and stabilized blood for RNA purification were kept at $4^{\circ} \mathrm{C}$ for about 18 hours, and then at $-20^{\circ} \mathrm{C}$. RNA from EDTA blood was, however, purified without prior storage. Plasma was stored at $-80^{\circ} \mathrm{C}$. A maximum of two freeze-thaw cycles was accepted for all protein analyses.

Table 1 Descriptive data on study subjects including clinical antibody levels

\begin{tabular}{|c|c|c|c|c|c|c|}
\hline Group & $\begin{array}{l}\text { No of cases }{ }^{a} \\
\text { (Females) }\end{array}$ & $\begin{array}{l}\text { Age (years) } \\
\text { median; } 80 \% \mathrm{CR}^{\mathrm{b}}\end{array}$ & $\begin{array}{l}\text { Marsh grade } \\
\text { span }\end{array}$ & $\begin{array}{l}\text { Anti-TG2 }(\mathrm{U} / \mathrm{mL})^{c} \\
\text { median; } 80 \% \mathrm{CR}\end{array}$ & $\begin{array}{l}\text { Anti-DGP }(\mathrm{U} / \mathrm{mL})^{\mathrm{d}} \\
\text { median; } 80 \% \mathrm{CR}\end{array}$ & $\begin{array}{l}\text { Anti-GL }(\mathrm{U} / \mathrm{mL})^{\mathrm{e}} \\
\text { median; } 80 \% \mathrm{CR}\end{array}$ \\
\hline Not CD & $14(8)$ & $8.8 ; 2.2-16$ & Marsh 0-1 & $0.25 ; 0.05-11$ & $0.95 ; 0.20-20$ & $0.60 ; 0.10-2.4$ \\
\hline Normalized CD ${ }^{f}$ & $15(13)$ & $12 ; 7.3-17$ & Marsh 0-1 & $3.4 ; 0.40-28$ & $2.6 ; 1.2-9.3$ & $0.80 ; 0.20-4.1$ \\
\hline Active $C^{g}$ & $20(12)$ & $5.9 ; 1.5-14$ & Marsh 2-3C & $201 ; 4.4-1997$ & $64 ; 5.6-392$ & $16 ; 2.4-167$ \\
\hline Under investigation ${ }^{h}$ & $3(3)$ & $15 ; 12-16$ & Marsh 0-1 & $15 ; 10-16$ & $7.1 ; 2.1-22$ & $1.9 ; 0.50-6.5$ \\
\hline
\end{tabular}

Study subjects are divided into groups depending on the diagnosis and the histopathologic assessment.

anitially, a total of 56 cases were included in the study, but three cases were later excluded due to low sample amount and one case was excluded due to histopathologically non-assessable biopsies, leaving 52 cases included in the analyses.

${ }^{\mathrm{b}} \mathrm{CR}=$ Central range.

${ }^{\mathrm{C}}$ Tissue transglutaminase autoantibodies (anti-TG2), positive result $\geq 7 \mathrm{U} / \mathrm{mL}$.

${ }^{\mathrm{d} D e a m i d a t e d}$ gliadin antibodies (anti-DGP), positive result $\geq 10 \mathrm{U} / \mathrm{mL}$.

${ }^{\text {e}}$ Gliadin antibodies (anti-GL), positive result $\geq 7 \mathrm{U} / \mathrm{mL}$.

${ }^{f}$ Cases with confirmed celiac disease and duodenal biopsies indicating a Marsh grade $0-1$, on a gluten-containing diet $(n=1)$ or a gluten-free diet $(n=14)$. Two cases had suboptimal (but assessable) biopsies.

${ }^{9}$ Cases with duodenal biopsies indicating a Marsh grade 2-3C, on a gluten-containing diet $(n=18)$ or a gluten-free diet ( $\left.n=2\right)$. One case had patchy lesions of the small intestine.

${ }^{\mathrm{h}}$ Cases under continued gluten challenge and observation due to elevated antibody titers but normal mucosa. Ranges for this group are represented by minimum and maximum values. 
The study was conducted under the approval of the Regional Ethical Review Board in Linköping.

\section{DNA purification}

DNA was isolated from EDTA blood using the EZ1 DNA Blood $350 \mu \mathrm{L}$ Kit and BioRobot EZ1 (Qiagen) according to the manufacturer's instructions.

\section{RNA purification and reverse transcription}

RNA from stabilized blood was purified using the Tempus Spin RNA Isolation Reagent kit (Life Technologies), and RNA from EDTA blood was purified using the QIAamp RNA Blood Mini kit (Qiagen), in both cases according to the manufacturer's instructions. The quality of the RNA from stabilized blood and EDTA blood was verified, and the RNA was reverse transcribed using a previously documented procedure [15]. The resulting cDNA and the remaining RNA were stored at $-80^{\circ} \mathrm{C}$.

\section{Histopathologic assessment}

Biopsies were assessed by a single experienced pathologist, blinded to all case data, in accordance with instructions for quality assurance and standardization assembled by the Swedish Society of Pathology. The status of the villi and crypts and the number of IELs were assessed for each biopsy. In cases where hematoxylin-eosin staining revealed an IEL number close to the ULN (25 IELs per 100 epithelial cells), an additional staining for CD3 was performed to better assess the number of IELs; when using CD3 staining, there should be $>30$ IELs per 100 epithelial cells to be indicative of CD. Hematoxylin-eosin staining was performed using the Tissue-Tek DRS 2000 Slide Stainer (Sakura, Alphen aan den Rijn, The Netherlands), and CD3 staining was performed using antibodies against CD3 (Dako, Glostrup, Denmark) and intelliPATH FLX (Biocare Medical, Concord, $\mathrm{CA})$. The histological changes were reported according to the modified Marsh scale $(0,1,2,3 \mathrm{~A}, 3 \mathrm{~B}$, or 3C) [16].

\section{Clinical antibody tests}

Detection of IgA anti-TG2, IgA anti-GL, and Immunoglobulin G (IgG) anti-DGP in serum or plasma was performed using EliA Celikey IgA (positive result $\geq 7 \mathrm{U} / \mathrm{mL}$ ), EliA Gliadin IgA (positive result $\geq 7 \mathrm{U} / \mathrm{mL}$ ), and EliA GliadinDP IgG (positive result $\geq 10 \mathrm{U} / \mathrm{mL}$ ), respectively, on Phadia250 (Thermo Fisher Scientific, Waltham, MA) as described by the manufacturer. In cases with total IgA levels below $0.07 \mathrm{~g} / \mathrm{L}$, detection of IgG anti-TG2 replaced IgA anti-TG2 (EliA Celikey IgG, Thermo Fisher Scientific). In order to distinguish results below the detection limit of an assay from missing data, the former were replaced with the detection limit divided by two.

\section{HLA typing and risk assessment}

DNA from each case was HLA-typed for $D R B 1, D Q A 1$ and $D Q B 1$ using a sequence-specific primer PCR method and capillary gel electrophoresis $[17,18]$. The risk gradient for CD based on HLA type was calculated for each case using relative genotype risks extracted from a Scandinavian population [8].

\section{Selection of genes for analysis}

Potential reference genes for the mRNA analysis were investigated using a Human Endogenous Control Plate (Life Technologies) containing assays for 32 potential reference genes, and cDNA from a total of nine blood RNA samples including three samples from cases with no mucosal injury (Marsh 0 ) and six with varying degrees of mucosal injury (Marsh 2-3C). Three potential reference genes (Additional file 1) were selected based on low sample-tosample variation in mRNA levels, as investigated using the NormFinder algorithm [19] in version 5.4.2 of the Genex software package (MultiD Analyses, Göteborg, Sweden). The three selected reference genes were analyzed in the complete dataset, and the final selection of reference gene/s was established using the complete dataset by means of both low sample-to-sample variation and an absence of group differences in expression.

Genes for analysis of mRNA and protein levels were selected by reviewing published studies on blood mRNA/ protein expression in $\mathrm{CD}$, and by functional context (Additional file 1).

\section{Protein analysis}

Multiplex detection of proteins in plasma was performed using Milliplex kits (Millipore, Billerica, MA) based on the Luminex xMAP technology, according to the manufacturer's instructions (Additional file 1). The analyses were performed on the Bio-Plex 200 system (Bio-Rad, Hercules, CA). The CD163 soluble protein was detected using an enzyme-linked immunosorbent assay (ELISA) according to instructions from the manufacturer (Additional file 1), and the results were obtained and analyzed using a Sunrise microplate absorbance reader combined with version 7.0 of the Magellan software package (Tecan Group Ltd, Männedorf, Switzerland). Standard curves were included in all protein analyses, and optimized using Bio-Plex Manager 6.1 (Bio-Rad) for all Milliplex assays, and the Akima method for curve fitting in Magellan v.7.0 for the ELISA. In order to distinguish results below the detection limit of an assay from missing data, the former were replaced with the lowest detected value of the assay divided by two.

\section{mRNA analysis}

Levels of mRNA were investigated using custom made TaqMan Array Cards (Life Technologies) containing 47 
gene expression assays including assays for the reference genes, or by using single assays and a previously documented procedure [15] (Additional file 1). Gene expression analysis on the TaqMan Array Cards was performed using the TaqMan Universal Master mix II without UNG and the recommended thermal profile (Life Technologies) on 300 ng cDNA in duplicates. Cards were prepared as recommended by the manufacturer, including analysis on the 7900HT Fast Real-time PCR system (Life Technologies).

For both TaqMan Array Cards and single assay results, quantification cycle $\left(\mathrm{C}_{\mathrm{q}}\right)$ values were established using version 1.0.2 of the ExpressionSuite software package (Life Technologies). The auto-baseline algorithm in the software was used to compensate for background noise for each amplification curve, and the thresholds were adjusted to the log-linear range and set to the same level for all samples within one assay. Missing $C_{q}$ values due to low copy numbers were replaced by the highest $\mathrm{C}_{\mathrm{q}}$ value available for the gene in question, increased by one cycle. The resulting $\mathrm{C}_{\mathrm{q}}$ values were normalized against selected reference gene/s (Genex).

\section{Statistical analysis}

Version 10 of the STATISTICA software package (StatSoft, Tulsa, OK) was used in all statistical analyses. Differential expression was investigated using KruskalWallis one-way analysis of variance by ranks, except for the analysis of differential expression in cases stratified based on having one or two $D Q B 1 * 02$ alleles, where the Mann-Whitney U test was used. Post-hoc comparisons of mean ranks of all pairs of groups were performed (significance level $\mathrm{p}<0.05$, two-sided significance levels with a Bonferroni adjustment) [20]. Spearman rank correlation was used to investigate relations between mRNA/protein levels and histopathology and $\mathrm{CD}$ risk gradient based on HLA type. For all statistical analyses, except the post-hoc comparisons, a false-discovery rate was used and set to $5 \%$ [21].

The diagnostic performance of individual assays and logistic regression models of assay combinations was evaluated using receiver operating characteristic (ROC) curve analysis (MedCalc Statistical Software version 13.1.2, MedCalc Software, Ostend, Belgium).

\section{Results}

\section{Differential blood marker expression}

Detectable levels were found for all protein markers $(\mathrm{n}=22$, Additional file 1), and all mRNA markers except for $I L 25$ ( $\mathrm{n}=48$, Additional file 1). CDKN1B was selected as the most stable reference gene, and used for normalization of all target mRNA levels.

In cases with active $\mathrm{CD}$ (Table 1, Active $\mathrm{CD}$ ), significantly increased levels were observed for CXCL11 protein $(\mathrm{p}=0.003$, Figure 1, Additional file 2) and TNFSF13B
mRNA ( $\mathrm{p}=0.001$, Figure 1, Additional file 2), in comparison to cases without a CD diagnosis (Table 1; Not CD). Additionally, TNFSF13B mRNA levels were significantly elevated in cases with confirmed CD and normalized histology (Table 1; Normalized CD), in comparison to cases without a CD diagnosis $(\mathrm{p}=0.001$, Figure 1 , Additional file 2). Levels of TNFRSF9 mRNA were significantly decreased in cases with active CD and in cases without a $\mathrm{CD}$ diagnosis, in comparison to $\mathrm{CD}$ cases with a normalized histology $(\mathrm{p}=0.005$ and $\mathrm{p}=0.02$, respectively, Figure 1, Additional file 2).

Previously established CD markers (anti-TG2, antiDGP, and anti-GL) were differentially expressed in active $\mathrm{CD}$ cases in comparison to cases with normalized $\mathrm{CD}$ $(\mathrm{p}<0.005)$ as well as cases without a CD diagnosis $(\mathrm{p}<$ $0.00005)$.

Stratification based on having one or two $D Q B 1 * 02$ alleles revealed no significant differences in levels of potential CD markers or in levels of previously established CD markers (anti-TG2, anti-DGP, and anti-GL), either when examining active $\mathrm{CD}$ cases only, or when looking at all $\mathrm{CD}$ cases together. Differences in expression in normalized $\mathrm{CD}$ cases alone could not be investigated, because all but two cases had one $D Q B 1 * 02$ allele.

\section{Correlation analysis}

Significant correlations were observed between Marsh grade (all cases) and levels of CXCL11 protein (Figure 2; Spearman rank correlation coefficient $\left[\mathrm{r}_{\mathrm{s}}\right]=0.50$ ), and $I L 21$ and IL15 mRNA ( $\mathrm{r}_{\mathrm{s}}=-0.46$ for both, data not shown).

Clinical antibody levels (anti-TG2, anti-DGP, and antiGL) displayed significant correlations with Marsh grade $\left(r_{s}=0.73,0.75\right.$, and 0.75, respectively; Figure 3$)$.

Levels of potential and previously established CD markers were not significantly correlated with HLA genotype risk for $\mathrm{CD}$.

\section{Clinical antibody tests}

All cases on a gluten-containing diet with anti-TG2 levels 10 times ULN or more $(n=13)$ showed a Marsh grade of 3A-3C and received a CD diagnosis. Correspondingly high levels of anti-DGP $(n=7)$ and anti-GL $(n=4)$ were less common, but all occurred in cases with an active $\mathrm{CD}$ diagnosis and a Marsh grade 3A-3C.

Of all cases with active $\mathrm{CD}$ on a gluten-containing diet $(\mathrm{n}=18)$ and all cases without CD diagnosis $(\mathrm{n}=14)$, antiTG2 failed to identify one case with active CD (Marsh 3C, anti-TG2 $3.4 \mathrm{U} / \mathrm{mL}$ ) and gave a false positive result in two cases without CD diagnosis (Marsh 0-1, anti-TG2 11-23 U/mL).

Anti-DGP yielded the same number of misclassifications as anti-TG2, but affected partially different cases, whereas anti-GL yielded substantially more misclassifications with 

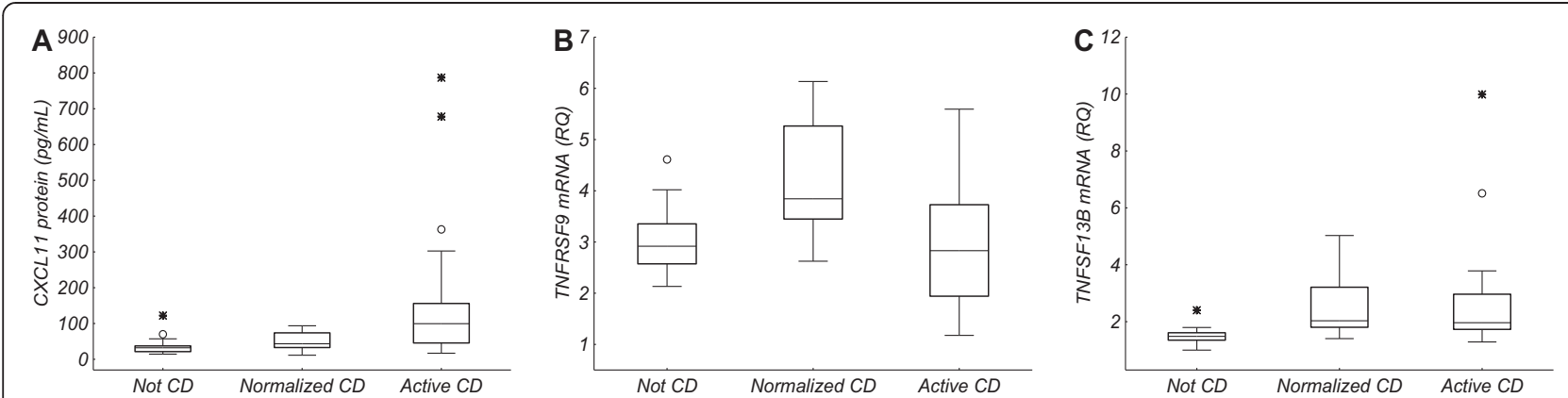

Figure 1 Protein/messenger RNA (mRNA) levels of potential celiac disease (CD) markers. Levels of (A) CXCL11 protein, (B) TNFRSF9 mRNA, and (C) TNFSF13B mRNA in cases without a CD diagnosis (Not CD), cases with confirmed CD and normalized duodenal histology (Normalized CD), and cases with active CD (Active CD). The box and the line represent the 25-75\% interquartile range and the median, respectively. The whiskers represent the non-outlier range, open circles represent outliers, and stars represent extreme values.

four false negative results, and one false positive result (data not shown).

Two cases with remaining enteropathy on a GFD (Marsh 2 - 3A, anti-TG2 2.0 - 5.4 U/mL) had normalized levels of all antibodies.

\section{Misclassified cases and cases under clinical investigation}

The case with active $\mathrm{CD}$ on a gluten-containing diet that was misclassified based on levels of anti-TG2 (see Clinical antibody tests) showed levels of the two CD up-regulated markers CXCL11 protein and TNFSF13B mRNA (Figure 1) that were above the $80 \%$ central range $(C R)$ of the group without $\mathrm{CD}$ and within the $80 \% \mathrm{CR}$ for the group with active CD (Additional file 2). For one of the two cases without $C D$ that were misclassified based on levels of anti-TG2 (see Clinical antibody tests), levels of CXCL11 protein were below the $80 \% \mathrm{CR}$ of the group with active $\mathrm{CD}$ and thus corresponded to the "Not CD" group (Additional file 2).

One of the two CD cases with remaining enteropathy on a GFD that were misclassified based on anti-TG2 (see Clinical antibody tests) showed a level of the TNFRSF9 mRNA marker for normalized CD (Figure 1) that was below the $80 \%$ CR of the group with normalized CD

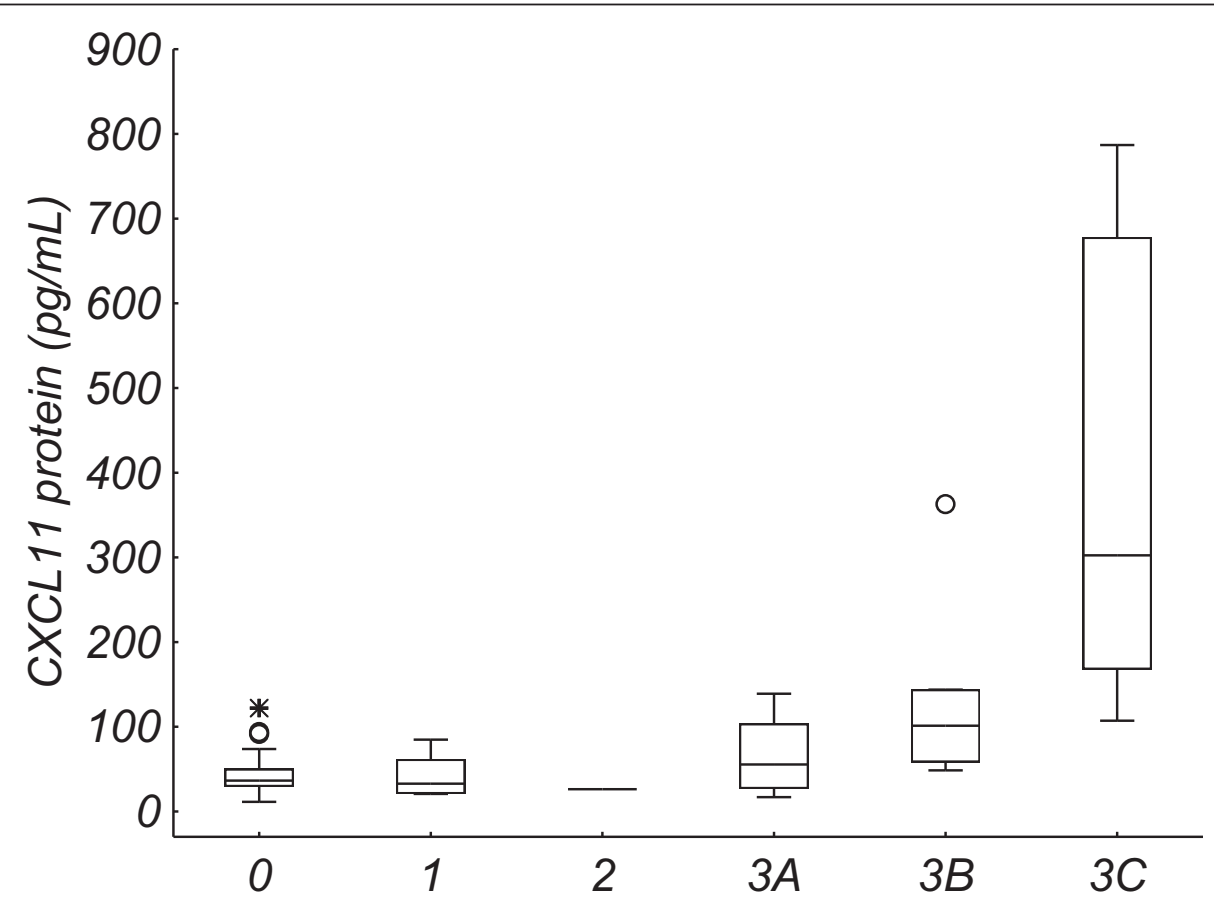

Figure 2 CXCL11 protein levels vs. Marsh grade. CXCL11 protein levels for Marsh grades $0(n=25), 1(n=7), 2(n=1), 3 A(n=8), 3 B(n=6)$, and $3 C(n=5)$. The box and the line represent the $25-75 \%$ interquartile range and the median, respectively. The whiskers represent the non-outlier range, open circles represent outliers, and stars represent extreme values. 


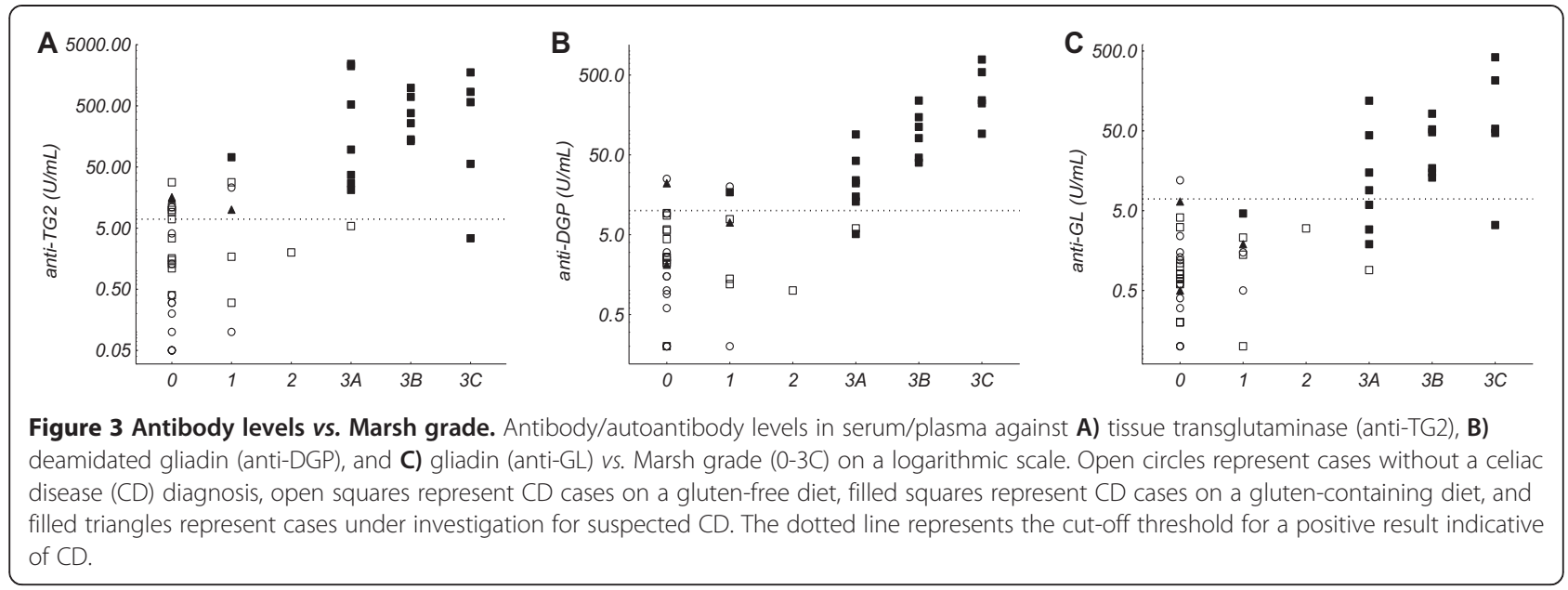

and within the $80 \% \mathrm{CR}$ for the group with active $\mathrm{CD}$ (Additional file 2).

The remaining results fell within the $80 \%$ CR for more than one group.

Cases included in the group under investigation (Table 1, Under investigation) were on a gluten-containing diet and under continuous monitoring for suspected $\mathrm{CD}$. Considering markers CXCL11 protein and TNFSF13B mRNA, the median of the group fell within the $80 \%$ CR for both the group without a $\mathrm{CD}$ diagnosis and the group with active CD (Additional file 2).

\section{ROC curve analysis}

ROC curve analysis of discrimination between cases with active $\mathrm{CD}$ and without $\mathrm{CD}$ (Figure $4 \mathrm{~A}$ and $\mathrm{B}$ ) revealed a larger area under the curve (AUC) for anti-TG2 (AUC = $0.97)$ in comparison to $C X C L 11$ protein $(\mathrm{AUC}=0.81)$, TNFSF13B mRNA (AUC $=0.85$ ), and a logistic regression model based on CXCL11 protein and TNFSF13B mRNA (AUC $=0.91$ ). A logistic regression model based on anti-TG2, CXCL11 protein, and TNFSF13B mRNA resulted in the highest AUC (0.98). However, compared to anti-TG2 alone, this improvement was not significant $(\mathrm{p}=0.54)$. ROC curve analysis of discrimination between cases with active $\mathrm{CD}$ and normalized $\mathrm{CD}$ (Figure $4 \mathrm{C}$ ) revealed an AUC of 0.90 for anti-TG2 and 0.78 for TNFRSF 9 mRNA. Compared to anti-TG2 alone, a logistic regression model based on anti-TG2 and TNFRSF9 mRNA resulted in an increased AUC of $0.93(\mathrm{p}=0.54)$.

\section{Discussion}

The prospect of a blood-based diagnostic procedure for $\mathrm{CD}$ is appealing. This is reflected by the new recommendations from ESPGHAN, which offer the option to omit biopsies in patients with anti-TG2 titers of 10 times ULN or more [14]. In patients with high pretest probability for CD in combination with anti-TG2 levels of 10 times ULN or more, the probability of having CD is high, but it decreases somewhat in patients with lower pretest probabilities [22]. All patients with anti-TG2 levels of 10 times ULN or more in the current study were diagnosed with $\mathrm{CD}$. However, in patients with lower antibody levels

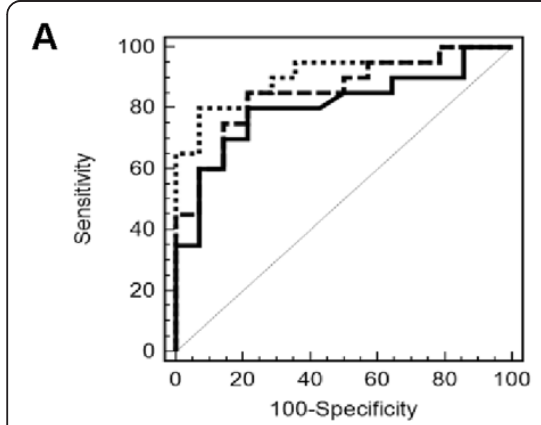

B

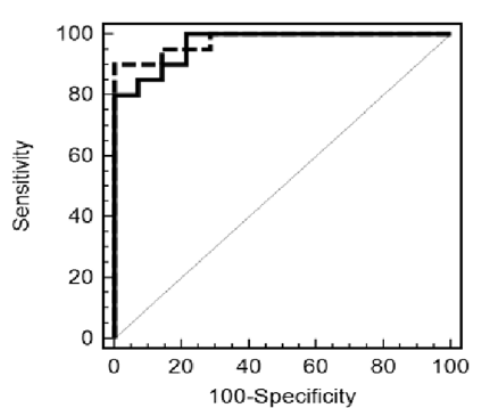

C

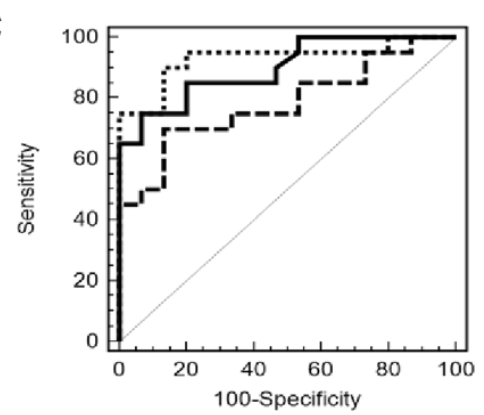

Figure 4 Receiver operating characteristic (ROC) curves. ROC curve analysis of discrimination between cases with active celiac disease (CD) and without CD (A and $\mathbf{B}$ ) or between cases with active CD and normalized CD (C). ROC curves in (A) correspond to CXCL11 protein (solid line), TNFSF13B messenger RNA (mRNA) (dashed line), and a logistic regression model of CXCL11 protein and TNFSF13B mRNA (dotted line). ROC curves in (B) correspond to tissue transglutaminase autoantibodies (anti-TG2) (solid line) and a logistic regression model of anti-TG2, CXCL11 protein, and TNFSF13B mRNA (dashed line). ROC curves in (C) correspond to anti-TG2 (solid line), TNFRSF9 mRNA (dashed line), and a logistic regression model of anti-TG2 and TNFRSF9 mRNA (dotted line). 
and/or of young age ( $<18$ months), blood-based diagnostics seem to be less clear-cut [23,24], and additional blood-based CD markers could be useful. Three potential blood-based CD markers (CXCL11 protein, TNFRSF9 mRNA, and TNFSF13B mRNA) were identified in the current study.

CXCL11 protein, which is an IFN- $\gamma$ and IFN- $\beta$ induced chemokine [25], and mRNA from TNFSF13B, which encodes a cytokine with a major role in B cell growth and survival [26], showed elevated levels in cases with active $\mathrm{CD}$ compared to cases without a CD diagnosis, which is consistent with previous studies of CXCL11 mRNA in small intestinal biopsies $[15,27]$ and TNFSF13B in serum [28]. An increased level of TNFSF13B mRNA was also evident in cases with $C D$ and normalized histology compared to cases without a CD diagnosis, which is also consistent with previous results [28]. Increased serum levels of TNFSF13B protein have previously been found in autoimmune diseases [26], and CXCL11 has also been implicated in autoimmune diseases [29].

CXCL11 protein level correlated significantly with Marsh grade, as did mRNA levels of IL21, which is involved in the control of the innate and adaptive immune responses [30], and IL15, which is involved in the innate immune response in $\mathrm{CD}$ [31].

A decreased level of mRNA from TNFRSF9, which is a receptor induced on the surface of $\mathrm{CD} 4+$ and $\mathrm{CD} 8+\mathrm{T}$ cells during activation [32], was found in cases with active $\mathrm{CD}$ and in cases without a $\mathrm{CD}$ diagnosis, compared with $\mathrm{CD}$ cases with normalized histology. This result differs from that in small intestinal biopsies [15], indicating tissue-specific regulation.

Potentially, CXCL11 protein, TNFRSF9 mRNA, and TNFSF13B mRNA might assist in the clinical diagnosis of $\mathrm{CD}$. The established blood-based CD marker antiTG2 misclassified one case with active CD and two cases without enteropathy on a gluten-containing diet, and two cases with remaining enteropathy on a GFD. In cases on a gluten-containing diet, CXCL11 protein showed the greatest potential as a marker, with results in accordance with histopathology for two out of three cases misclassified by anti-TG2. For cases on a GFD with remaining enteropathy, results for TNFRSF9 mRNA were in accordance with histopathology for one out of two cases.

ROC curve analysis showed that, as a single test, the already established anti-TG2 assay outperformed the new potential blood-based CD markers. However, it might be possible to increase the diagnostic performance by considering several assay results jointly. Adding new markers to the anti-TG2 assay produced a slight, though non-significant, increase in diagnostic performance. At present, the data is too limited for any firm conclusions regarding added diagnostic value, and our analysis provided no suggestions as to the potential CD status of cases in the group under investigation.

Several proteins in serum/plasma have previously been suggested as potential blood-based $C D$ markers, for example regenerating gene I $\alpha$ protein and intestinal fatty acid binding protein [33,34]. Recently, Galatola et al. proposed a discriminant model based on the expression of four genes including REL and TNFAIP3 [35], which along with TNFSF13B and TNFRSF9 (identified as potential CD markers in the current study) are involved in regulation of the NF- $\mathrm{KB}$ complex [32,36,37]. Furthermore, the NF- $\mathrm{kB}$ complex is involved in the IFN- $\beta$ induced transcription of CXCL11 [38], and REL is involved in the transcriptional activation of TNFSF13B [26]. This indicates that additional investigations into NF- $\mathrm{kB}$ interacting proteins could reveal new potential markers for diagnosis and monitoring of $\mathrm{CD}$.

\section{Conclusions}

The CD markers identified in this study further emphasize the significance of components related to NF- $\mathrm{kB}$ regulation in relation to $C D$. However, the diagnostic relevance of CXCL11, TNFSF13B, TNFRSF9, and other NF-kB interacting proteins recognized by pathway analysis needs to be further investigated.

\section{Human genes}

The human genes discussed in this article are presented in Additional file 1.

\section{Additional files}

Additional file 1: Genes selected for messenger RNA (mRNA) and/ or protein detection in human blood. Protein/mRNA levels were

investigated in cases with active celiac disease (CD), cases with confirmed CD and normalized histology, cases without a CD diagnosis, and cases under investigation for suspected CD. Some genes were selected based on their context; others were selected based on information from published studies.

Additional file 2: Descriptive data on differentially expressed potential blood-based celiac disease (CD) markers. Study subjects are divided into groups depending on the diagnosis and the histopathologic assessment.

\section{Abbreviations}

CD: Celiac disease; TG2: Tissue transglutaminase; DGP: Deamidated gliadin; GL: Native gliadin; IELs: Intraepithelial lymphocytes; anti-TG2: Autoantibodies against tissue transglutaminase; ESPGHAN: European Society of Paediatric Gastroenterology, Hepatology and Nutrition; ULN: Upper limit of normal; mRNA: Messenger RNA; anti-DGP: Antibodies against deamidated gliadin; anti-GL: Antibodies against native gliadin; $C_{q}$ : Quantification cycle; ROC: Receiver operating characteristic; CR: Central range; AUC: Area under the curve.

\section{Competing interests}

The authors declare that they have no competing interests.

\section{Authors' contributions}

JS conceived of the study, and all authors participated in the study design. $H B, U J$, and JS collected material for the study. HB carried out all the laboratory work. HB, JS, and MF contributed to data analysis and 
interpretation. HB drafted the manuscript, with help from all other authors, especially JS. All authors read and approved the final manuscript.

\section{Acknowledgements}

This work was supported by Futurum - the Academy for Healthcare, Jönköping County Council, and the Medical Research Council of Southeast Sweden. The authors wish to thank all participating patients, Research Nurse Inga-Lena Hultman at the Department of Pediatrics, and the staff at the Endoscopy Department and the Surgical Department at Ryhov County Hospital, Jönköping, Sweden. The authors also wish to thank Mats Wolving, Sahlgrenska University Hospital, Göteborg, for performing the histopathologic assessments, and Ewa Lavant, Labmedicine Skåne, Malmö, for assistance with HLA typing.

\section{Author details}

'Division of Medical Diagnostics, Ryhov County Hospital, Jönköping, Sweden. ${ }^{2}$ Department of Pediatrics, Ryhov County Hospital, Jönköping, Sweden. ${ }^{3}$ Department of Clinical and Experimental Medicine, Division of Occupational and Environmental Medicine and Linköping Academic Research Center (LARC), Linköping University, Linköping, Sweden. ${ }^{4}$ Östergötland County Council \& Department of Health and Medicine, Division of Pharmacological Research, R\&D Unit in Local Health Care, Linköping University, Linköping, Sweden.

Received: 24 April 2014 Accepted: 29 September 2014 Published: 9 October 2014

\section{References}

1. Ludvigsson JF, Leffler DA, Bai JC, Biagi F, Fasano A, Green PH, Hadjivassiliou M, Kaukinen K, Kelly CP, Leonard JN, Lundin KE, Murray JA, Sanders DS, Walker MM, Zingone F, Ciacci C: The Oslo definitions for coeliac disease and related terms. Gut 2013, 62(1):43-52.

2. Tack GJ, Verbeek WH, Schreurs MW, Mulder CJ: The spectrum of celiac disease: epidemiology, clinical aspects and treatment. Nat Rev Gastroenterol Hepatol 2010, 7(4):204-213.

3. van Heel DA, Franke L, Hunt KA, Gwilliam R, Zhernakova A, Inouye M, Wapenaar MC, Barnardo MC, Bethel G, Holmes GK, Feighery C, Jewell D, Kelleher D, Kumar P, Travis S, Walters JR, Sanders DS, Howdle P, Swift J, Playford RJ, McLaren WM, Mearin ML, Mulder CJ, McManus R, McGinnis R, Cardon LR, Deloukas P, Wijmenga C: A genome-wide association study for celiac disease identifies risk variants in the region harboring IL2 and IL21. Nat Genet 2007, 39(7):827-829.

4. Dubois PC, Trynka G, Franke L, Hunt KA, Romanos J, Curtotti A, Zhernakova A, Heap GA, Adany R, Aromaa A, Bardella MT, van den Berg LH, Bockett NA, de la Concha EG, Dema B, Fehrmann RS, Fernandez-Arquero M, Fiatal S, Grandone E, Green PM, Groen HJ, Gwilliam R, Houwen RH, Hunt SE, Kaukinen K, Kelleher D, Korponay-Szabo I, Kurppa K, MacMathuna P, Maki M, et al: Multiple common variants for celiac disease influencing immune gene expression. Nat Genet 2010, 42(4):295-302

5. Sollid LM, Markussen G, Ek J, Gjerde H, Vartdal F, Thorsby E: Evidence for a primary association of celiac disease to a particular HLA-DQ alpha/beta heterodimer. J Exp Med 1989, 169(1):345-350.

6. Sollid LM: Coeliac disease: dissecting a complex inflammatory disorder. Nat Rev Immunol 2002, 2(9):647-655.

7. Ploski R, Ek J, Thorsby E, Sollid LM: On the HLA-DQ(alpha $1{ }^{*} 0501$, beta $\left.1{ }^{*} 0201\right)$-associated susceptibility in celiac disease: a possible gene dosage effect of DQB1*0201. Tissue Antigens 1993, 41(4):173-177.

8. Margaritte-Jeannin P, Babron MC, Bourgey M, Louka AS, Clot F, Percopo S, Coto I, Hugot JP, Ascher H, Sollid LM, Greco L, Clerget-Darpoux F: HLA-DQ relative risks for coeliac disease in European populations: a study of the European genetics cluster on celiac disease. Tissue Antigens 2004, 63(6):562-567.

9. Megiorni F, Mora B, Bonamico M, Barbato M, Nenna R, Maiella G, Lulli P, Mazzilli MC: HLA-DQ and risk gradient for celiac disease. Hum Immunol 2009, 70(1):55-59.

10. Hunt KA, Zhernakova A, Turner G, Heap GA, Franke L, Bruinenberg M, Romanos J, Dinesen LC, Ryan AW, Panesar D, Gwilliam R, Takeuchi F, McLaren WM, Holmes GK, Howdle PD, Walters JR, Sanders DS, Playford RJ, Trynka G, Mulder CJ, Mearin ML, Verbeek WH, Trimble V, Stevens FM, O'Morain C, Kennedy NP, Kelleher D, Pennington DJ, Strachan DP, McArdle $W L$, et al: Newly identified genetic risk variants for celiac disease related to the immune response. Nat Genet 2008, 40(4):395-402.
11. Trynka G, Hunt KA, Bockett NA, Romanos J, Mistry V, Szperl A, Bakker SF, Bardella MT, Bhaw-Rosun L, Castillejo G, de la Concha EG, de Almeida RC, Dias KR, van Diemen CC, Dubois PC, Duerr RH, Edkins S, Franke L, Fransen K, Gutierrez J, Heap GA, Hrdlickova B, Hunt S, Plaza Izurieta L, Izzo V, Joosten LA, Langford C, Mazzilli MC, Mein CA, Midah V, et al: Dense genotyping identifies and localizes multiple common and rare variant association signals in celiac disease. Nat Genet 2011, 43(12):1193-1201.

12. Ostensson M, Monten C, Bacelis J, Gudjonsdottir AH, Adamovic S, Ek J, Ascher H, Pollak E, Arnell H, Browaldh L, Agardh D, Wahlstrom J, Nilsson S, Torinsson-Naluai A: A possible mechanism behind autoimmune disorders discovered by genome-wide linkage and association analysis in celiac disease. PLoS One 2013, 8(8):e70174.

13. Kneepkens CM, von Blomberg BM: Clinical practice: celiac disease. Eur J Pediat 2012, 171(7):1011-1021

14. Husby S, Koletzko S, Korponay-Szabo IR, Mearin ML, Phillips A, Shamir R, Troncone R, Giersiepen K, Branski D, Catassi C, Lelgeman M, Maki M, Ribes-Koninckx C, Ventura A, Zimmer KP: European Society for Pediatric Gastroenterology, Hepatology, and Nutrition guidelines for the diagnosis of celiac disease. J Pediatr Gastroenterol Nutr 2012, 54(1):136-160.

15. Bragde $H$, Jansson U, Jarlsfelt I, Soderman J: Gene expression profiling of duodenal biopsies discriminates celiac disease mucosa from normal mucosa. Pediatr Res 2011, 69(6):530-537.

16. Rostami K, Kerckhaert J, Tiemessen R, von Blomberg BM, Meijer JW, Mulder CJ: Sensitivity of antiendomysium and antigliadin antibodies in untreated celiac disease: disappointing in clinical practice. Am J Gastroenterol 1999, 94(4):888-894.

17. Lavant EH, Carlson JA: A new automated human leukocyte antigen genotyping strategy to identify DR-DQ risk alleles for celiac disease and type 1 diabetes mellitus. Clin Chem Lab Med 2009, 47(12):1489-1495.

18. Lavant EH, Agardh DJ, Nilsson A, Carlson JA: A new PCR-SSP method for HLA DR-DQ risk assessment for celiac disease. Clin Chim Acta 2011, 412(9-10):782-784.

19. Andersen $\mathrm{CL}$, Jensen $J \mathrm{~L}$, Orntoft TF: Normalization of real-time quantitative reverse transcription-PCR data: a model-based variance estimation approach to identify genes suited for normalization, applied to bladder and colon cancer data sets. Cancer Res 2004, 64(15):5245-5250.

20. Siegel S, Castellan NJ: Nonparametric statistics for the behavioral sciences. 2nd edition. New York: McGraw-Hill; 1988.

21. Benjamini $Y$, Hochberg $Y$ : Controlling the false discovery rate: a practical and powerful approach to multiple testing. J Roy Stat Soc B 1995 57(1):289-300.

22. Vermeersch P, Geboes K, Marien G, Hoffman I, Hiele M, Bossuyt X: Defining thresholds of antibody levels improves diagnosis of celiac disease. Clin Gastroenterol Hepatol 2013, 11(4):398-403. quiz e332.

23. Giersiepen K, Lelgemann M, Stuhldreher N, Ronfani L, Husby S, Koletzko S, Korponay-Szabo IR: Accuracy of diagnostic antibody tests for coeliac disease in children: summary of an evidence report. J Pediatr Gastroenterol Nutr 2012, 54(2):229-241

24. Lagerqvist $C$, Dahlbom I, Hansson $T$, Jidell $E$, Juto $P$, Olcen $P$, Stenlund $H$, Hernell O, Ivarsson A: Antigliadin immunoglobulin A best in finding celiac disease in children younger than 18 months of age. J Pediatr Gastroenterol Nutr 2008, 47(4):428-435.

25. Rani MR, Foster GR, Leung S, Leaman D, Stark GR, Ransohoff RM: Characterization of beta-R1, a gene that is selectively induced by interferon beta (IFN-beta) compared with IFN-alpha. J Biol Chem 1996, 271(37):22878-22884.

26. Lahiri A, Pochard P, Le Pottier L, Tobon GJ, Bendaoud B, Youinou P, Pers JO: The complexity of the BAFF TNF-family members: implications for autoimmunity. J Autoimmun 2012, 39(3):189-198.

27. Diosdado B, van Bakel H, Strengman E, Franke L, van Oort E, Mulder CJ, Wijmenga C, Wapenaar MC: Neutrophil recruitment and barrier impairment in celiac disease: a genomic study. Clin Gastroenterol Hepatol 2007, 5(5):574-581.

28. Fabris M, Visentini $D$, De Re V, Picierno A, Maieron R, Cannizzaro R, Villalta D, Curcio F, De Vita S, Tonutti E: Elevated B cell-activating factor of the tumour necrosis factor family in coeliac disease. Scand J Gastroenterol 2007, 42(12):1434-1439.

29. Lacotte S, Brun S, Muller S, Dumortier H: CXCR3, inflammation, and autoimmune diseases. Ann N Y Acad Sci 2009, 1173:310-317.

30. Sarra M, Cupi ML, Pallone F, Monteleone G: Interleukin-21 in immune and allergic diseases. Inflamm Allergy Drug Targets 2012, 11(4):313-319. 
31. De Nitto D, Monteleone I, Franze E, Pallone F, Monteleone G: Involvement of interleukin-15 and interleukin-21, two gamma-chain-related cytokines, in celiac disease. World J Gastroenterol 2009, 15(37):4609-4614.

32. Jang IK, Lee ZH, Kim YJ, Kim SH, Kwon BS: Human 4-1BB (CD137) signals are mediated by TRAF2 and activate nuclear factor-kappa B. Biochem Biophys Res Commun 1998, 242(3):613-620.

33. Adriaanse MP, Tack GJ, Passos VL, Damoiseaux JG, Schreurs MW, van Wijck K, Riedl RG, Masclee AA, Buurman WA, Mulder CJ, Vreugdenhil AC: Serum I-FABP as marker for enterocyte damage in coeliac disease and its relation to villous atrophy and circulating autoantibodies. Aliment Pharmacol Ther 2013, 37(4):482-490.

34. Planas R, Pujol-Autonell I, Ruiz E, Montraveta M, Cabre E, Lucas-Martin A, Pujol-Borrell R, Martinez-Caceres E, Vives-Pi M: Regenerating gene lalpha is a biomarker for diagnosis and monitoring of celiac disease: a preliminary study. Trans/ Res 2011, 158(3):140-145.

35. Galatola M, Izzo V, Cielo D, Morelli M, Gambino G, Zanzi D, Strisciuglio C, Sperandeo MP, Greco L, Auricchio R: Gene expression profile of peripheral blood monocytes: a step towards the molecular diagnosis of celiac disease? PLoS One 2013, 8(9):e74747.

36. Rickert RC, Jellusova J, Miletic AV: Signaling by the tumor necrosis factor receptor superfamily in B-cell biology and disease. Immunol Rev 2011, 244(1):115-133.

37. Trynka G, Zhernakova A, Romanos J, Franke L, Hunt KA, Turner G, Bruinenberg M, Heap GA, Platteel M, Ryan AW, de Kovel C, Holmes GK, Howdle PD, Walters JR, Sanders DS, Mulder CJ, Mearin ML, Verbeek WH, Trimble V, Stevens FM, Kelleher D, Barisani D, Bardella MT, McManus R, van Heel DA, Wijmenga C: Coeliac disease-associated risk variants in TNFAIP3 and REL implicate altered NF-kappaB signalling. Gut 2009, 58(8):1078-1083.

38. Rani MR, Asthagiri AR, Singh A, Sizemore N, Sathe SS, Li X, DiDonato JD, Stark GR, Ransohoff RM: A role for NF-kappa B in the induction of beta-R1 by interferon-beta. J Biol Chem 2001, 276(48):44365-44368

doi:10.1186/1471-230X-14-176

Cite this article as: Bragde et al:: Potential blood-based markers of celiac disease. BMC Gastroenterology 2014 14:176.

\section{Submit your next manuscript to BioMed Central and take full advantage of:}

- Convenient online submission

- Thorough peer review

- No space constraints or color figure charges

- Immediate publication on acceptance

- Inclusion in PubMed, CAS, Scopus and Google Scholar

- Research which is freely available for redistribution 